\title{
Analysis of Chemical Compositions of Portland Cement and Limestone from Four Geopolitical Zones of Nigeria
}

\author{
Abdulhanan Onimisi Ahmed1, Anayo Christian Etonihu ${ }^{2 *}$, Nwaze Obini Nweze ${ }^{3}$ \\ ${ }^{1}$ Department of Chemical Sciences, Federal University of Kashere, Gombe, Nigeria \\ ${ }^{2}$ Department of Chemistry, Nasarawa State University, Keffi, Nigeria \\ ${ }^{3}$ Department of Statistics, Nasarawa State University, Keffi, Nigeria \\ Email: *criseto@yahoo.com
}

How to cite this paper: Ahmed, A.O., Etonihu, A.C. and Nweze, N.O. (2022) Analysis of Chemical Compositions of Portland Cement and Limestone from Four Geopolitical Zones of Nigeria. Journal of Minerals and Materials Characterization and Engineering, 10, 113-126.

https://doi.org/10.4236/jmmce.2022.102009

Received: January 5, 2022

Accepted: March 6, 2022

Published: March 9, 2022

Copyright $\odot 2022$ by author(s) and Scientific Research Publishing Inc. This work is licensed under the Creative Commons Attribution International License (CC BY 4.0).

http://creativecommons.org/licenses/by/4.0/

\begin{abstract}
Cement, a major binding material in concrete making, influences the quality of concrete so produced with it; as such its chemistry dictates the chemistry of the concrete. Poor quality cement has recently been implicated as the main causes of incessant building collapses in Nigeria. The physicochemical analysis of limestone used in the production of various brands of Portland cement in four geopolitical zones of Nigeria (north east NE, north west NW, north central NC, and south west SW) was investigated using standard methods. Each of the limestone and cement samples was randomly collected from their respective sample points at the four different geopolitical zones of Nigeria. Each of the collected samples was ground and sieved to $2 \mathrm{~mm}$ mesh size. The limestone was rich in lime content that ranged from $45.91 \% \pm 0.30 \%$ to $49.0 \% \pm 0.19 \%$. Among the cement samples, percent $\mathrm{SiO}_{2}$ ranged from $19.95 \pm 0.25(\mathrm{NW})$ to $20.18 \pm 1.02(\mathrm{NC}), \mathrm{Al}_{2} \mathrm{O}_{3} 4.98 \pm 0.18(\mathrm{NW})$ to $5.82 \pm$ 0.38 (NE), $\mathrm{Fe}_{2} \mathrm{O}_{3} 2.76 \pm 1.00$ (NE) to $3.82 \pm 0.21$ (SW), $\mathrm{CaO} 60.18 \pm 0.27$ (NE) to $65.10 \pm 0.98(\mathrm{NC}), \mathrm{MgO} 1.93 \pm 0.04(\mathrm{NC})$ to $2.50 \pm 0.10(\mathrm{NE}), \mathrm{SO}_{3} 0.93 \pm$ 0.50 (NE) to $2.02 \pm 0.13(\mathrm{NW})$. The results showed that virtually all the cement samples analyzed conformed well to the BSEN 196-2 standard. However, the loss on ignition (LOI) deviated considerably (7.82\% to $8.72 \%$ ) from $4 \%$ maximum by the standard. Also, the lime saturation factor $(99.70 \%)$ obtained for north central cement was slightly higher than the specified range of 92.0 to $98.0 \%$. It could be deduced from this study that the various cements available in Nigerian market from the four geopolitical zones are of good quality. Nevertheless, other processes that lead to the production of a good concrete such as the mix ratio of cement, gravel, sand and water, use and quality of iron rods, and other building materials need to be professionally checked for
\end{abstract}


quality assurance. The findings from this study can be a useful guide to the chemist, environmentalist, construction industry, and the general public on the quality of cements available in Nigerian market.

\section{Keywords}

Geopolitical Zones of Nigeria, Clinker, Limestone, Portland Cement

\section{Introduction}

Ordinary Portland cement or Portland cement is as a hydraulic cement (cement that not only hardens by reacting with water but also forms a water-resistant product) produced by pulverizing clinkers which consist essentially of hydraulic calcium silicates, usually containing one or more of the forms of calcium sulphate as an underground addition [1]. Portland cement clinker is a hydraulic material which consists of at least two-thirds by mass of calcium silicates $\left(3 \mathrm{CaO} \cdot \mathrm{SiO}_{2}\right.$ and $\left.2 \mathrm{CaO} \cdot \mathrm{SiO}_{2}\right)$, the remainder consisting of aluminium and iron containing clinker phases and other compounds. Furthermore, Portland cement is caustic, so it can cause chemical burns. The powder can cause irritation on severe exposure, results in lung cancer and can contain some hazardous components such as crystalline silica and hexavalent chromium.

Portland cement is the most common type of cement in general use around the world for the construction of building, roads, concrete, mortar and other local purposes. Some of the raw materials used in the manufacture of ordinary Portland cement include lime which is obtained from limestone or dolomite; silica from clay or laterites; alumina and iron oxide from laterites or clay. All these components interact with one another in the appropriate proportions in the kiln to form series of complex products. Gypsum is normally added during grinding of clinker to control the setting time of the cement [2]. The low cost and widespread availability of the various raw materials used in the production of ordinary Portland cement makes it one of the cheapest materials widely used over the last century throughout the world. Concrete produced from Portland cement is one of the most versatile construction materials available in the world [3].

Limestone is a sedimentary rock composed largely of minerals calcite and aragonite which are different crystal forms of calcium carbonate $\left(\mathrm{CaCO}_{3}\right)$. Most limestone is composed of skeletal fragments of marine organisms such as coral, forams and mollusks. Limestone is a general term for rocks that contain $80 \%$ or more of calcium or magnesium carbonates, examples are chalk, marble, iolite and marl [4]. About $10 \%$ of sedimentary rocks are limestone that often contain a variable amount of silica, alumina etc.

The quality of cement may differ from one plant to another due to changes in raw material properties, kiln temperatures as well as fineness upon grinding. These changes can significantly affect the concrete properties especially when different cements are used. For example the tricalcium aluminate $\left(\mathrm{C}_{3} \mathrm{~A}\right)$ and al- 
kali content of cement have been found to possess dominant effect on drying shrinkage of concrete [5]. Similarly, [6] studied the effect of fineness of cement on early strength of concrete. They observed that the coarser cement exhibits compressive strengths well below those of the finer ones at all ages tested with less heat of hydration, which results in a substantially lower semi-adiabatic temperature rise.

Cement is one of the most used basic materials which is in demand in virtually all areas of construction [7], and a major binding material in making concrete; it influences the quality of the concrete so produced with it. Therefore, its chemistry dictates the chemistry of concrete [8]. The use of poor quality cement in structural and constructional work has caused a lot of problems, including loss of lives and properties, and has been identified to have negative effects on the overall performance of cement in concrete. As a result, a lot of structures collapse. Poor quality cement has been implicated as one of the major causes of increasing building collapse in Nigeria [9].

The various chemical components of cement have an effect on the physical properties of the cement product. The American Society for Testing Materials designation C150 [10] and the American Association for State Highway Transportation Officials designation [11] have specified physical requirements for each type of cements. These properties include fineness, soundness, consistency, setting time, flexural/compressive strength, heat of hydration, specific gravity and loss on ignition [12]. Each of these properties has an influence on the performance of cement in concrete. The fineness of cement, for example, affects the rate of hydration; greater fineness increases the surface available for hydration causing greater early strength and more rapid generation of heat [13] [14].

In Nigeria the uses of poor quality cement in structural and constructional works may cause a lot of problems to the citizens, which may include cracking and collapse of structures that may lead to loss of lives and properties. As a result, quality assurance of ordinary Portland cement or Portland cement has become a very important and critical factor in cement industries. The assessment and comparative studies of the chemical components of the various cements from different manufacturers available in Nigerian market will ascertain whether they conform to available standards. This information is timely as it's a critical factor to cement chemists and the findings from this research work will be a guide to chemists, environmentalists, regulatory bodies and general public on the quality of cements in Nigerian market.

\section{Materials and Methods}

\subsection{Sample Collection}

Portland cement and limestone used in this study were randomly collected from their respective sample points at four different geopolitical zones of Nigeria (i.e. northeast, NE; northwest, NW; north central, NC, and southwest, SW). The zones were selected based on the cement industries in those locations. Included 
in this study are Ashaka cement (in Gombe State), cement of northern Nigeria (in Sokoto State), Obajana cement (in Kogi State) and Ibese cement (in Ogun State), respectively.

\subsection{Sample Pre-Treatment}

Each of the samples $(50 \mathrm{~g})$ collected was ground, sieved through a $2 \mathrm{~mm}$ mesh, and stored in different sample sacks until analysis.

\subsection{Determination of Physicochemical Parameters}

\subsubsection{Determination of Moisture Content}

Each sample ( $1 \mathrm{~g}$ ) was weighed into a previously cleaned and weighed porcelain crucible and placed in an oven set at $1100^{\circ} \mathrm{C}$ for $1 \mathrm{~h}$, and heated at the rate of $18^{\circ} \mathrm{C} / \mathrm{min}$. Thereafter, the crucible was removed from the oven until it was completely cool, and was re-weighed. The difference in the final and weights of the sample gave the moisture content. This procedure was repeated for all the samples according to standard methods [15] [16].

\subsubsection{Loss on Ignition}

Each sample $(1 \mathrm{~g})$ was weighed into a cleaned and weighed platinum crucible and placed in a muffle furnace set at $1000^{\circ} \mathrm{C}$ for $1 \mathrm{~h}$. Thereafter, the crucible was removed from the furnace and kept in a desiccator until it was completely cool, and was re-weighed. The difference in the final and initial weights of the sample gave the loss on ignition. This procedure was repeated for all the other samples [15] [16].

\subsubsection{Insoluble Residue}

Each sample ( $1 \mathrm{~g}$ ) was weighed into a preciously cleaned platinum crucible. $3 \mathrm{~g}$ of $\mathrm{Na}_{2} \mathrm{CO}_{3}$ (Riedel-Dottaen) was added to the crucible and stirred thoroughly with the aid of the flattened end of a glass rod. The crucible was placed in a muffle furnace set at $1000^{\circ} \mathrm{C}$ for $1 \mathrm{~h}$ for fusion. After fusion, $5 \mathrm{~cm}^{3}$ concentrated $\mathrm{HCI}$ (BDH, 37\%) was added to dissolve the sample, to which $10 \mathrm{~cm}^{3}$ distilled water was added and warmed, and the solution was filtered through Whatman No. 40 filter paper and the residue was washed with distilled water. The filtrate was set aside for $\mathrm{SO}_{3}$ determination. The filter paper containing the residue was placed into weighed platinum crucible and ignited in a muffle furnace at $1000^{\circ} \mathrm{C}$ for 30 mins. Then, the crucible was removed and kept in a desiccator until it was completely cool, and re-weighed. The insoluble residue was obtained by difference expressed as a percentage of the initial weight of the sample taken. For cement sample, fusing is not required. $1 \mathrm{~g}$ of cement sample was weight into a dried beaker. $25 \mathrm{~cm}^{3}$ of distilled water was added followed by the addition of $5 \mathrm{~cm}^{3}$ of concentrated $\mathrm{HCl}$ and stirred thoroughly, warmed, and to which $25 \mathrm{~cm}^{3}$ of distilled water was added. To this was added $5 \mathrm{~cm}^{3}$ of $\mathrm{HCl}$ and the solution later digested at $60^{\circ} \mathrm{C}$ for 15 mins. This solution was filtered using Whatman No. 40 and washed thoroughly with distilled water. The filtrate was also kept aside for 
$\mathrm{SO}_{3}$ determination according to standard methods [15] [16]. This procedure was repeated for all the samples.

\subsubsection{Determination of $\mathrm{SO}_{3}$}

The filtrate set aside during the determination of insoluble reside was diluted to $250 \mathrm{~cm}^{3}$ with distilled water and boiled to reduce the filtrate to $150 \mathrm{~cm}^{3} .10 \mathrm{~cm}^{3}$ of hot $10 \%$ barium chloride solution was added drop wisely to the filtrate with continuous stirring for 30 mins, until all the precipitate was formed. The liquor containing the precipitate was digested on water bath for $4 \mathrm{~h}$. Precipitate was filtered using Whatman filter paper No.42. The residue was washed with hot distilled water. The filter paper along with the residue was re-weighed in a crucible and ignited for $1 \mathrm{~h}$. The $\mathrm{SO}_{3}$ content was obtained by difference expressed as a percentage of initial weight of sample taken during insoluble residue determination [15]. This procedure was repeated for all the samples.

\subsubsection{Determination of Silica $\left(\mathrm{SiO}_{2}\right)$}

Each sample $(0.5 \mathrm{~g})$ was weighed into a clean dry platinum crucible. $1.5 \mathrm{~g}$ of $\mathrm{Na}_{2} \mathrm{CO}_{3}$ was added to the sample and mixed thoroughly and the crucible put in a muffle furnace at $1000^{\circ} \mathrm{C}$ for $1 \mathrm{~h}$ to fuse. After fusion was completed, $10 \mathrm{~cm}^{3}$ concentrated $\mathrm{HCl}$ was added to dissolve the fused sample. The solution was digested at low temperature to almost dryness.

For the cement sample, $0.5 \mathrm{~g}$ was weighted into a tarred clean dry beaker to which $1.5 \mathrm{~g}$ of ammonium chloride was added and mixed thoroughly by using the tip of a glass rod to avoid lumps, followed by the addition of $5 \mathrm{~cm}^{3}$ of concentrated $\mathrm{HCl}$ with thorough stirring. The solution was digested at low temperature to almost dryness. $20 \mathrm{~cm}^{3}$ of distilled water was be added with stirring, followed by the addition of $3 \mathrm{~cm}^{3}$ concentrated HCI in which a yellow color was observed. The solution was filtered through Whatman No 40 filter paper. The precipitate was washed with hot distilled water and the filtrate kept aside for combined oxide determination. The filter paper along with the residue was placed into a weighed platinum crucible and ignited for $1 \mathrm{~h}$. The silica content was obtained by difference expressed as a percentage of the initial weight of the sample taken [15] [16]. This procedure was repeated for all the samples.

\subsubsection{Determination of Combined Oxide $\left(\mathrm{R}_{2} \mathrm{O}_{3}\right)$}

Ammonium chloride (BDH, $2.3 \mathrm{~g}$ ) was added to the filtrate set aside during silica determination and boiled for 10 mins. 3 drops of conc. $\mathrm{HNO}_{3}(\mathrm{BDH}, 69 \%)$ was added and the solution was allowed to boil for some minutes. On boiling, 20 $\mathrm{cm}^{3}$ of concentrated ammonia was added until precipitate formed. To the precipitate was added little and then excess concentrated $\mathrm{NH}_{3}$ until no color change was observed. The solution was filtered through Whatman No. 41 filter paper and the residue was washed with hot distilled water. The filtrate was set aside for $\mathrm{CaO}$ determination. The residue was washed with $2 \%$ ammonium nitrate solution then with hot distilled water till the residue was free from chloride. The filter paper along with the residue was placed into a weighted crucible and ignited 
for $1 \mathrm{~h}$. The combined oxide was obtained by difference as a percentage of the initial weight of the sample taken for the determination of silica [15] [16]. This procedure was repeated for all the samples.

\subsubsection{Volumetric Determination of Iron Oxide $\left(\mathrm{Fe}_{2} \mathrm{O}_{3}\right)$}

Each separate sample $(0.5 \mathrm{~g})$ of limestone and dolomite was added into a clean platinum crucible. $1.5 \mathrm{~g}$ of $\mathrm{Na}_{2} \mathrm{CO}_{3}$ was added to the sample with thorough stirring. The crucible along with sample was kept in a muffle furnace at $1000^{\circ} \mathrm{C}$ for $1 \mathrm{~h}$ to fuse. After fusion, $10 \mathrm{~cm}^{3}$ of concentrated $\mathrm{HCl}$ was added to dissolve the fused sample followed by the addition of $10 \mathrm{~cm}^{3}$ of distilled water and boiled for 15 mins. For cement sample, $0.5 \mathrm{~g}$ of cement was weighed into a clean dried beaker followed by the addition of $10 \mathrm{~cm}^{3}$ distilled water with stirring to break the lumps. $10 \mathrm{~cm}^{3}$ of concentrated $\mathrm{HCl}$ was added and boiled for $15 \mathrm{mins}, 5 \%$ stannous chloride solution was added drop-wisely until the solution decolorized. After decolourization, the solution was allowed to cool to room temperature after which $20 \mathrm{~cm}^{3}$ of saturated mercuric chloride solution was added and stirred. $20 \mathrm{~cm}^{3}$ of acid mixture $\left(\mathrm{H}_{2} \mathrm{SO}_{4}+\mathrm{H}_{3} \mathrm{PO}_{4}\right.$; Fluka, $95 \%-97 \%$ and $\mathrm{BDH}$, respectively) was added then two drops of barium diphenylsulphanate (BDS) indicator, and was titrated against $0.4 \mathrm{M} \mathrm{K}_{2} \mathrm{Cr}_{2} \mathrm{O}_{7}$ until a purple color was observed. This procedure was repeated for all the samples [15] [16].

The percentage of iron oxide was obtained by the formula:

$$
\frac{0.4 \times \text { Volume of } \mathrm{K}_{2} \mathrm{Cr}_{2} \mathrm{O}_{7} \text { Consumed }}{\text { Weight of sample }}
$$

\subsubsection{Determination of Alumina $\left(\mathrm{Al}_{2} \mathrm{O}_{3}\right)$}

This was obtained by difference. The combined oxide $\left(\mathrm{R}_{2} \mathrm{O}_{3}\right)$ is the combination of both iron oxide and aluminum oxide,

$$
\begin{aligned}
& \mathrm{R}_{2} \mathrm{O}_{3}=\mathrm{Fe}_{2} \mathrm{O}_{3}+\mathrm{Al}_{2} \mathrm{O}_{3} \\
& \mathrm{Al}_{2} \mathrm{O}_{3}=\mathrm{R}_{2} \mathrm{O}_{3}-\mathrm{Fe}_{2} \mathrm{O}_{3}
\end{aligned}
$$

\subsubsection{Determination of Lime ( $\mathrm{CaO})$}

The filtrate set aside during determination of combined oxide was boiled to reduce the volume to $150 \mathrm{~cm}^{3}$ after which $30 \mathrm{~cm}^{3}$ of $5 \%$ ammonium oxalate (May $\&$ Baker) solution was added until a white precipitate formed. The liquor containing the precipitate was digested on a water bath for $4 \mathrm{~h}$, filtered through Whatman No. 42 filter paper and filtrate set aside for magnesium oxide determination. The filter paper along with the residue was placed into a weighed platinum crucible and ignited for $1 \mathrm{~h}$. The percentage line content was obtained by difference, expressed as a percentage of the initial weight taken for determination of silica. This procedure was repeated for all the samples [15] [16].

\subsubsection{Gravimetric Determination of $\mathrm{MgO}$}

To about $250 \mathrm{~cm}^{3}$ of the filtrate set aside during lime determination, $10 \mathrm{~cm}^{3}$ concentrated HCI was added and then reduced to $150 \mathrm{~cm}^{3}$ by boiling. The solution was allowed to cool to room temperature after which $40 \mathrm{~cm}^{3}$ of concen- 
trated ammonia was added. $10 \mathrm{~cm}^{3}$ of ammonium dihydrogenorthophosphate solution was added and stirred thoroughly until a cloudy precipitate. The liquor containing the precipitate was kept in a dark place overnight after which it was filtered through Whatman No. 40 filter paper and washed with hot distilled water. The filter paper containing the precipitate was placed inside a weighed crucible and ignited for $1 \mathrm{~h}$. The $\mathrm{MgO}$ content was obtained by difference, expressed as a percentage to the initial weight of sample taken for determination of silica [15] [16].

\subsection{Determination of $\mathrm{K}_{2} \mathrm{O}$ by Flame Atomic Absorption Spectrophotometer (AA32 Model)}

Digestion of Samples

Each sample $(0.5 \mathrm{~g})$ was weighed into $50 \mathrm{~cm}^{3}$ beaker then $10 \mathrm{~cm}^{3}$ of distilled water was added to form slurry. $10 \mathrm{~cm}^{3}$ of $2 \mathrm{M} \mathrm{HCl} \mathrm{(1:19)} \mathrm{was} \mathrm{added} \mathrm{and} \mathrm{the} \mathrm{mix-}$ ture was warmed until the sample dissolved. Glass rod was used to break any lumps formed and the solution was filtered through filter paper into $100 \mathrm{~cm}^{3}$ volumetric flask. The residue was washed with boiling water until the filtrate was about $80 \mathrm{~cm}^{3}$ in the $100 \mathrm{~cm}^{3}$ volumetric flask. The filtrate was allowed to cool to room temperature after which $10 \mathrm{~cm}^{3}$ of $2 \mathrm{M}$ phosphoric acid (1:19) was added to the solution and made to the mark with distilled water. The solution was aspirated into the flame photometer and the absorbance of potassium was measured at $768 \mathrm{~nm}$ [15].

\subsection{X-Ray Fluorescence (XRF) Determinations}

\section{Preparation of the Sample}

Each sample (10 g) was weighed into a weighted boat. Four tablets of ethylene glycol were added to the weighed sample and ground together with the aid of an automated milling machine. The ground mixture was pelletized with the aid of a pelletizing machine inside a ring after which the ring put into the XRF (Thermo scientific; model ARL-990) for analysis [17].

The cement control parameters such as lime saturation factor (LSF), silica ratio (SR) and alumina/iron ratio (AR) influences the performance of cement and it is most often used for control purposes (Taylor, 1990). These values are obtained from the formulae shown in Equations (4) to (6):

$$
\begin{gathered}
\mathrm{LSF}=\frac{\mathrm{CaO}}{2.8 \mathrm{SiO}_{2}+1.2 \mathrm{Al}_{2} \mathrm{O}_{3}+0.65 \mathrm{Fe}_{2} \mathrm{O}_{3}} \times 100 \\
\mathrm{SR}=\frac{\mathrm{SiO}_{2}}{\mathrm{Al}_{2} \mathrm{O}_{3}+\mathrm{Fe}_{2} \mathrm{O}_{3}} \\
\mathrm{AR}=\frac{\mathrm{Al}_{2} \mathrm{O}_{3}}{\mathrm{Fe}_{2} \mathrm{O}_{3}}
\end{gathered}
$$

\section{Statistical Analysis}

The data obtained were analyzed using mean, standard deviation, and ANOVA 
for statistical significance.

\section{Results and Discussion}

The XRF composition of cements from the four geopolitical regions of Nigeria is presented in Table 1.

A comparison of the XRF and gravimetric compositions (Table 2) of cement from the four geopolitical zones showed that most of the parameters were higher in the XRF than the gravimetric values, except for $\mathrm{MgO}, \mathrm{SiO}_{2}, \mathrm{Al}_{2} \mathrm{O}_{3}$ and $\mathrm{SO}_{3}$. This difference may have been due to losses usually associated with gravimetric method.

The composition of the oxides in various brands of cement as determined indicated that they are within the stipulated limits given by [18]. The values of loss on ignition (LOI) obtained from this analysis were found to be higher when compared with the result obtained by [19] whose result included the analysis of imported cement samples. LOI is a measure of the amount of $\mathrm{CO}_{2}$ and water present in the cement which are emitted when cement is incinerated up to $950^{\circ} \mathrm{C}$. This indicated that the samples of this research work are likely to possess

Table 1. XRF composition of cement from the four geopolitical regions of Nigeria.

\begin{tabular}{ccccccc}
\hline Parameter (\%) & N.E & N.W & N.C & S.W & p-Value & BSEN 196-2 [18] \\
\hline $\mathrm{SiO}_{2}$ & $20.00 \pm 1.60^{\mathrm{a}}$ & $19.95 \pm 0.25^{\mathrm{a}}$ & $20.18 \pm 1.02^{\mathrm{a}}$ & $20.16 \pm 0.26^{\mathrm{a}}$ & 0.988 & $18.0-24.0$ \\
$\mathrm{Al}_{2} \mathrm{O}_{3}$ & $5.82 \pm 0.38^{\mathrm{a}}$ & $4.98 \pm 0.18^{\mathrm{a}}$ & $5.34 \pm 0.09^{\mathrm{a}}$ & $5.04 \pm 0.12^{\mathrm{a}}$ & 0.117 & $2.6-8.0$ \\
$\mathrm{Fe}_{2} \mathrm{O}_{3}$ & $2.76 \pm 1.00^{\mathrm{a}}$ & $3.20 \pm 0.18^{\mathrm{a}}$ & $3.67 \pm 0.08^{\mathrm{a}}$ & $3.82 \pm 0.21^{\mathrm{a}}$ & 0.206 & $1.5-7.0$ \\
$\mathrm{CaO}$ & $60.18 \pm 0.27^{\mathrm{a}}$ & $61.40 \pm 2.65^{\mathrm{ac}}$ & $65.10 \pm 0.98^{\mathrm{b}}$ & $62.75 \pm 1.15^{\mathrm{ac}}$ & 0.0126 & $1.0-69.0$ \\
$\mathrm{MgO}$ & $2.50 \pm 0.10^{\mathrm{a}}$ & $2.20 \pm 0.22^{\mathrm{ab}}$ & $1.93 \pm 0.04^{\mathrm{bc}}$ & $2.00 \pm 0.20^{\mathrm{bc}}$ & 0.009 & $0.5-4.0$ \\
$\mathrm{SO}_{3}$ & $0.93 \pm 0.05^{\mathrm{a}}$ & $2.02 \pm 0.13^{\mathrm{b}}$ & $1.86 \pm 0.14^{\mathrm{c}}$ & $1.68 \pm 0.04^{\mathrm{c}}$ & 0.000 & $0.2-4.0$ \\
\hline
\end{tabular}

BSEN196-2 = British Standard Specification; Means with different superscripts across the row are significant $(\mathrm{P} \leq 0.05)$. Means with the same superscript across the rows are not significant $(P \geq 0.05)$.

Table 2. Gravimetric compositions of cement from the four geopolitical regions of Nigeria.

\begin{tabular}{|c|c|c|c|c|c|c|}
\hline Parameter (\%) & N.E & N.W & N.C & S.W & p-Value & BSEN 196-2 [18] \\
\hline $\mathrm{SiO}_{2}$ & $19.0 \pm 0.25^{\mathrm{a}}$ & $22.10 \pm 0.76^{\mathrm{b}}$ & $19.50 \pm 0.07^{b}$ & $21.90 \pm 0.58^{c}$ & 0.00 & $18.0-24.0$ \\
\hline $\mathrm{Al}_{2} \mathrm{O}_{3}$ & $5.18 \pm 0.18^{\mathrm{a}}$ & $5.85 \pm 0.01^{\mathrm{b}}$ & $5.01 \pm 0.03^{\mathrm{a}}$ & $6.25 \pm 0.14^{\mathrm{c}}$ & 0.00 & $2.6-8.0$ \\
\hline $\mathrm{Fe}_{2} \mathrm{O}_{3}$ & $2.50 \pm 0.17^{\mathrm{a}}$ & $5.00 \pm 0.08^{b}$ & $3.23 \pm 0.40^{c}$ & $4.85 \pm 0.05^{\mathrm{b}}$ & 0.00 & $1.5-7.0$ \\
\hline $\mathrm{CaO}$ & $58.60 \pm 0.40^{\mathrm{a}}$ & $64.25 \pm 0.23^{b}$ & $60.50 \pm 0.67^{c}$ & $61.58 \pm 0.64^{\mathrm{b}}$ & 0.00 & $61.0-69.0$ \\
\hline $\mathrm{MgO}$ & $1.20 \pm 0.10^{\mathrm{a}}$ & $3.50 \pm 0.06^{\mathrm{b}}$ & $1.80 \pm 0.14^{\mathrm{c}}$ & $3.52 \pm 0.05^{\mathrm{b}}$ & 0.00 & $0.5-4.0$ \\
\hline $\mathrm{SO}_{3}$ & $2.01 \pm 0.15^{\mathrm{a}}$ & $3.50 \pm 0.08^{b}$ & $1.57 \pm 0.21^{\mathrm{a}}$ & $2.85 \pm 0.09^{c}$ & 0.00 & $0.2-4.0$ \\
\hline IR & $1.70 \pm 0.02^{\mathrm{a}}$ & $2.20 \pm 0.04^{\mathrm{b}}$ & $1.50 \pm 0.16^{\mathrm{a}}$ & $1.80 \pm 0.16^{\mathrm{a}}$ & 0.00 & $\leq 1.5$ \\
\hline LOI & $8.10 \pm 0.03^{\mathrm{a}}$ & $7.82 \pm 0.10^{\mathrm{a}}$ & $8.72 \pm 0.06^{\mathrm{b}}$ & $8.50 \pm 0.24^{\mathrm{ac}}$ & 0.003 & $\leq 4.0$ \\
\hline $\mathrm{MC}$ & $0.25 \pm 0.08^{\mathrm{a}}$ & $0.50 \pm 0.09^{b}$ & $0.20 \pm 0.03^{\mathrm{a}}$ & $0.35 \pm 0.08^{\mathrm{ac}}$ & 0.006 & - \\
\hline Free Lime & $1.04 \pm 0.05^{\mathrm{a}}$ & $1.20 \pm 0.12^{\mathrm{b}}$ & $0.88 \pm 0.04^{\mathrm{c}}$ & $0.98 \pm 0.04^{\mathrm{ac}}$ & 0.002 & $\leq 2.0$ \\
\hline
\end{tabular}


more water and $\mathrm{CO}_{2}$ that are readily available to evaporate during burning. This may be partly attributed to improper and prolonged stage or adulteration of cement during transportation [20]. The percentage of sulphite $\left(\mathrm{SO}_{3}\right)$ present in all the samples were found to be less than $3.5 \%$ which is the upper limit for sulphite $\left(\mathrm{SO}_{3}\right)$ content in cement, hence there may be no risk of failure due to heat curing of concrete [21].

The British standards specified that the lime $(\mathrm{CaO})$ content should be within the range $63 \%$ to $67 \%$. It was observed that all the brands of cement analyzed fall within this specified range as shown in Table 1 and Table 2. The proper lime content is limited due to the lower early strength produced when the lime content of ordinary Portland cement is too low and unsoundness when the lime content is too high [22] [23]. High lime content is associated with early strength which favors ultimate strength that develops gradually over a long period of time [23]. In other to increase the strength, it is necessary to raise the lime content, or grand finer or combining both, but this may be with an adverse effect since high temperature will be required to burn the high lime mixture [24]. It was observed that the entire sample analyzed did not exceed the maximum $\mathrm{MgO}$ limit of $4.0 \%$, as specified by [18]. [24] stated that higher magnesia content may be detrimental to the soundness of the cement resulting in expansion crack commonly known as magnesia expansion. This occurs when the magnesia content is beyond the upper limit as specified by [18]. The magnesia appears in clinker as free $\mathrm{MgO}$ (Periclase), this reacts with water to form $\mathrm{Mg}(\mathrm{OH})_{2}$ which is the slowest reaction among all other hardening reactions [25]. Since $\mathrm{Mg}(\mathrm{OH})_{2}$ occupies a larger volume than $\mathrm{MgO}$ and it is formed on the same spot where the periclase particle is located, it can split apart the binding of the hardened cement paste thereby causing cracking [23] [26]. The free lime was found to be within the specified limit of the British standard for all the samples analyzed. There is no advantage in adding extra lime unless it is brought into combination with other constituents. If appreciable lime is left uncombined, it may cause expansion which may possibly result into cracking of the mortar [23] [27].

The statistical analysis (ANOVA) of the cement samples indicated that for $\mathrm{SiO}_{2}, \mathrm{Al}_{2} \mathrm{O}_{3}, \mathrm{Fe}_{2} \mathrm{O}_{3}$ there is no significant difference across the geopolitical zones as the p-value of the parameters were greater than 0.05; but for $\mathrm{CaO}, \mathrm{MgO}$ and $\mathrm{SO}_{3}$ in N.E and N.W samples there is significant difference, the p-value is less than 0.05 .

Limestone and dolomite constitute a group of raw-materials commonly referred to as carbonate rocks [28], that affect the composition and properties of cement. The XRF composition of limestone from the four geopolitical regions of Nigeria is presented in Table 3.

[29] reported that strength at 2 days was increased by $\mathrm{K}_{2} \mathrm{O}$ additions of up to $1.5 \%$, and $\mathrm{Na}_{2} \mathrm{O}$ additions of up to $1.5 \%$ when the degree of sulfatisation was $100 \%$; Strengths after 2 and 7 days were increased by $\mathrm{K}_{2} \mathrm{O}$ and $\mathrm{Na}_{2} \mathrm{O}$ contents up to about $1.5 \%$. Higher alkali contents and supersulfatisation reduced strengths. 
Table 3. XRF composition of limestone from the four geopolitical regions of Nigeria.

\begin{tabular}{cccccc}
\hline Parameter (\%) & N.E & N.W & N.C & S.W & p-value \\
\hline $\mathrm{SiO}_{2}$ & $11.63 \pm 0.12^{\mathrm{a}}$ & $9.58 \pm 0.12^{\mathrm{b}}$ & $1.50 \pm 0.09^{\mathrm{c}}$ & $4.08 \pm 0.08^{\mathrm{d}}$ & 0.000 \\
$\mathrm{Al}_{2} \mathrm{O}_{3}$ & $3.94 \pm 0.08^{\mathrm{a}}$ & $2.90 \pm 0.09^{\mathrm{b}}$ & $2.66 \pm 0.24^{\mathrm{b}}$ & $2.22 \pm 0.03^{\mathrm{c}}$ & 0.000 \\
$\mathrm{Fe}_{2} \mathrm{O}_{3}$ & $1.59 \pm 0.14^{\mathrm{a}}$ & $1.35 \pm 0.06^{\mathrm{a}}$ & $0.94 \pm 0.02^{\mathrm{b}}$ & $1.88 \pm 0.22^{\mathrm{c}}$ & 0.000 \\
$\mathrm{CaO}$ & $45.91 \pm 0.30^{\mathrm{a}}$ & $46.42 \pm 0.16^{\mathrm{b}}$ & $48.90 \pm 0.12^{\mathrm{c}}$ & $49.0 \pm 0.19^{\mathrm{c}}$ & 0.000 \\
$\mathrm{MgO}$ & $0.44 \pm 0.04^{\mathrm{a}}$ & $0.94 \pm 0.03^{\mathrm{b}}$ & $0.71 \pm 0.03^{\mathrm{c}}$ & $1.01 \pm 0.04^{\mathrm{b}}$ & 0.000 \\
$\mathrm{SO}_{3}$ & $0.73 \pm 0.03^{\mathrm{a}}$ & $0.58 \pm 0.02^{\mathrm{b}}$ & $0.19 \pm 0.03^{\mathrm{c}}$ & $0.25 \pm 0.02^{\mathrm{d}}$ & 0.000 \\
$\mathrm{~K}_{2} \mathrm{O}$ & $0.57 \pm 0.03^{\mathrm{a}}$ & $0.20 \pm 0.02^{\mathrm{b}}$ & $0.06 \pm 0.03^{\mathrm{c}}$ & $0.07 \pm 0.03^{\mathrm{c}}$ & 0.000 \\
$\mathrm{Na}_{2} \mathrm{O}$ & $0.08 \pm 0.01^{\mathrm{a}}$ & $0.0 \pm 0.00^{\mathrm{b}}$ & $0.0 \pm 0.00^{\mathrm{b}}$ & $0.0 \pm 0.00^{\mathrm{b}}$ & 0.000 \\
\hline
\end{tabular}

Means with different superscripts across the row are significant $(\mathrm{P} \leq 0.05)$. Means with the same superscript across the rows are not significant $(\mathrm{P} \geq 0.05)$.

The strengths at 28 and 90 days were reduced by additions of $\mathrm{Na}_{2} \mathrm{O}$ and $\mathrm{K}_{2} \mathrm{O}$; for equal additions, $\mathrm{Na}_{2} \mathrm{O}$ had a greater influence than $\mathrm{K}_{2} \mathrm{O}$. For $\mathrm{K}_{2} \mathrm{O}$, the optimum degree of sulfatisation was $60 \%-70 \%$ and for $\mathrm{Na}_{2} \mathrm{O}$ it was $90 \%-100 \%$. The reduction in strength at 28 and 90 days in cements containing $\mathrm{K}_{2} \mathrm{O}$ can be offset by increasing the silica ratio, regardless of whether there was an optimum degree of sulfatisation. This action is only successful in cements containing $\mathrm{Na}_{2} \mathrm{O}$. The strengths after 28 and 90 days were increasingly reduced by increasing $\mathrm{K}_{2} \mathrm{O}$ and $\mathrm{Na}_{2} \mathrm{O}$ contents. For equally high contents of alkali oxides, the strengths after 28 and 90 days were reduced to a greater extent by $\mathrm{Na}_{2} \mathrm{O}$ than by $\mathrm{K}_{2} \mathrm{O}$. Equal molar proportions of the two alkali oxides lowered the strengths by equal amounts where the degree of sulfatisation was below $100 \%$. For alumina ratios between 1.3 and 2.7, the optimum degree of sulfatisation was about $60 \%$ for $\mathrm{K}_{2} \mathrm{O}$ and about $100 \%$ for $\mathrm{Na}_{2} \mathrm{O}$. The reduction in strength after 28 and 90 days by $\mathrm{K}_{2} \mathrm{O}$ contents up to $\sim 1.5 \%$ can be offset by lowering the alumina ratio where there is an optimum degree of sulfatisation, but the reduction in strength caused by $\mathrm{Na}_{2} \mathrm{O}$ contents up to $1.5 \%$ is only partly compensated.

Table 4 shows the cement control parameters such as lime saturation factor (LSF), silica ratio (SR) and alumina to iron ratio (AR), that influence the performance of cement and it is most often used for control purposes [30]. The LSF controls the $\mathrm{C}_{3} \mathrm{~S}$ and $\mathrm{C}_{2} \mathrm{~S}$ ratio in the clinker. A clinker with a higher LSF value will pose a high proportion of $C_{3} S$ to $C_{2} S$ ratio than that with a low LSF value [19].

Table 4 indicated that the N.C cement sample had higher LSF value of $99.70 \%$ when compared with the value obtained for N.E cement sample (92.62\%), so the corresponding proportion of $\mathrm{C}_{3} \mathrm{~S}$ to $\mathrm{C}_{2} \mathrm{~S}$ in N.C cement is $65.16 \%$ to $8.79 \%$, while that of N.E cement is $43.46 \%$ to $24.63 \%$. The silica ratio (SR) and Alumina ratio (AR) of the cement samples considered in this study did not significantly deviate from each other, hence the calcium silicate and aluminate in the cement as considered in this study are within the acceptable limits. A high silica ratio indicated 
Table 4. Silica ratio, alumina ratio, and lime saturation factor of cement from four geopolitical regions of Nigeria.

\begin{tabular}{|c|c|c|c|c|c|c|}
\hline Parameters (\%) & N.E & N.W & N.C & S.W & p-value & BSEN 196-2 \\
\hline Lime Sat. Factor (LSF) & $92.62 \pm 0.13^{\mathrm{a}}$ & $96.06 \pm 0.09^{\mathrm{b}}$ & $99.70 \pm 0.65^{c}$ & $96.57 \pm 0.34^{\mathrm{b}}$ & 0.000 & $92.0-98.0$ \\
\hline Silica Ratio (SR) & $2.33 \pm 0.09^{\mathrm{a}}$ & $2.44 \pm 0.10^{\mathrm{a}}$ & $2.24 \pm 0.08^{\mathrm{a}}$ & $2.28 \pm 0.04^{\mathrm{a}}$ & 0.074 & $2.0-3.0$ \\
\hline Alumina Ratio (AR) & $2.11 \pm 0.11^{\mathrm{a}}$ & $1.55 \pm 0.07^{\mathrm{b}}$ & $1.46 \pm 0.04^{\mathrm{bc}}$ & $1.32 \pm 0.13^{\mathrm{c}}$ & 0.000 & $1.0-4.0$ \\
\hline
\end{tabular}

Means with different superscripts across the row are significant $(\mathrm{P} \leq 0.05)$; means with the same superscript across the rows are not significant $(\mathrm{P} \geq 0.05)$.

that more calcium silicate is present in the clinker and less aluminate and ferrite. The conventional silica ratio (SR) is between 2.0 and 3.0. A high AR value means that there will be proportionally more aluminate than ferrite in the clinker. In Ordinary Portland Cement (OPC) clinker, the alumina (AR) ratio is within the range of 1 to 4 [30].

Table 4 showed that silica ratio (SR) varied slightly among the cement samples from the four different geopolitical zones being highest in N.W (2.44\%) and lowest in N.C (2.44\%). The alumina ratio (AR) was highest in N.E (2.11\%) but lowest in S.W (1.32\%). The LSF is the molar ratio of $\mathrm{CaO}$ to the other three main oxides. The lime saturation factor (LSF) ranged from $99.70 \%$ in N.C to $92.62 \%$ in cement samples from north eastern Nigeria. There will be a condition where the amount of $\mathrm{CaO}$ present will be sufficient to produce only $\mathrm{C}_{3} \mathrm{~S}, \mathrm{C}_{3} \mathrm{~A}$ and $\mathrm{C}_{4} \mathrm{AF}$ and under these circumstances the LSF is 1.0. If the LSF is increased in a clinker raw feed while maintaining the SR and AR, effects are observed in the clinker such as quantity of alite increases showing potential strength improvement; quantity of belite decreases, indication of more heat evolution on hydration; and higher burning temperatures are indicative that burnability decreases. The variation of parameters SR, AR, or LSF significantly affects the quality of the cement clinker. [31] investigated on laboratory clinker made from cement raw meals with a lime saturation factor of $93 \%$, and an alumina ratio of 2.0 . The silica ratio (1.6 - 3.2), the alkali contents and the degree of sulfatisation were varied. Strength tests showed that: increasing silica ratio strength was generally increased, and reduced with increasing $\mathrm{SO}_{3}$ content. Further investigations on laboratory clinker made from cement raw meals with a uniform lime saturation factor of $93 \%$ and a silica ratio of 2.4. The alumina ratio (1.3 - 2.7), alkali contents $\left(\mathrm{Na}_{2} \mathrm{O}\right.$ and $\mathrm{K}_{2} \mathrm{O}$ each $\left.\sim 0 \%-2 \%\right)$ and the degree of sulfatisation were varied. Strength tests showed that the strengths always increased with falling alumina ratio. [29] reported that when the investigations were with a silica ratio of 2.4 and an alumina ratio of 2.0, the lime saturation factor, the alkali contents and the degree of sulfatisation were varied. Strength tests showed that the strengths were increased with increasing lime saturation factor. Cements rich in tricalcium silicate showed high strength at early ages, while those which were low in this compound showed much lower strengths at early ages, but a progressive increase with age, so that at 6 months the differences in the strengths were relatively small. At 12 months the strengths of the two groups of cements were about equal 
[32]. The cement control parameters LSF and AR, showed significant difference across the zones $0.05(\mathrm{p} \leq 0.05)$, unlike the SR parameter, that showed no significant difference across the zones ( $\mathrm{p} \geq 0.05$ ).

\section{Conclusion}

The physicochemical analysis of limestone used in the production of Portland cement in four geopolitical zones of Nigeria (north east, north west, north central, and north east) was investigated. The results obtained from this research work show that virtually all the cement samples analyzed conformed well to the BSEN 196-2 standard. However, the loss on ignition (LOI) deviated considerably (7.82\% to $8.72 \%$ ) from $4 \%$ maximum by the standard. Also, the lime saturation factor $(99.70 \%)$ obtained for north central cement was slightly higher than the specified range of $92.0 \%$ to $98.0 \%$. Although poor quality cement has recently been implicated as the main cause of incessant building collapses in Nigeria, it could be deduced from this study that the various cements available in Nigerian market from the four geopolitical zones are of good quality. Nevertheless, other processes that lead to the production of a good concrete such as the mix ratio of cement, gravel, sand and water, use and quality of iron rods, and other building materials need to be professionally checked for quality assurance.

\section{Acknowledgements}

The authors hereby acknowledge TetFund for providing the Institution-Based funding for this work.

\section{Conflicts of Interest}

The authors declare no conflicts of interest regarding the publication of this paper.

\section{References}

[1] American Society for Testing Materials (ASTM) (2015) Standard Test Method for Air Content of Hydraulic Cement Mortar, C185-15a. American Society for Testing Materials, West Conshocken. http://www.astm.org

[2] Nerville, A.M. (1981) Properties of Concrete, 3rd Edition, Pitman Publishers Ltd London, 1-61.

[3] Coumes, C.C., Simone, C., Didier, N., Xavier, B. and Stephen, L. (2006) Formulating a Low Alkalinity, High Resistance and Low-Heat Concrete for Radioactive Waste Repositories. Cement and Concrete Research Journal, 36, 2152-2163. https://doi.org/10.1016/j.cemconres.2006.10.005

[4] Cassar, J. (2010) The Use of Limestone. Smith, B. J., Ed., Geographical Society of London, 13-23. https://doi.org/10.1144/SP331.2

[5] Johannes, V.C., Taylor, P.C. and Tennis, P.D. (2005) Effect of Cement Characteristics on Concrete Properties. EB226, Portland Cement Association, Skokie, 56-62.

[6] Dale, P.B., Gaurav, S. and Jason, W. (2008) Early-Age Properties of Cement-Based Materials: Influenced of Cement Fineness. ASCE Journal of Materials in Civil Engineering, 20, 502-508. https://doi.org/10.1061/(ASCE)0899-1561(2008)20:7(502) 
[7] Zerbo, L., Sawa-Dogo, M., Sawadogo, Y., Salogo, S., Oue-Drago, M., Seynou, M., Lecomte-Nana, G. and Blanchart, P. (2021) Usability of a Natural Tuff as Admixture in Clinker and Its Influence on the Physico-Chemical and Mechanical Properties of Mortar. Journal of Minerals and Materials Characterization and Engineering, 9, 480-498.

[8] Bhanumathidas, N. and Kalidas, N. (2003) Metabolism of Cement Chemistry. The Indian Concrete Journal, 7, 1304-1306.

[9] The Nation (2015, November 16) Curbing Building Collapse through Cement Standardization.

http://thenationonlineng.net/curbing-building-collapse-through-cement-standardiz ation

[10] American Society for Testing Materials (2008) Standard Test Method for Testing of Physical Parameters of Cement C150-92. ASTM International, West Conshocken, 128-170.

[11] American Association for State Highway Transportation Officials (2006) Standard Test Method for Testing of Physical Parameters of Cement, M 85-60. AASHTO International, West Conshocken, 55-70.

[12] Rajput, R.K. (2006) Engineering Material Including Construction. 3rd Edition, S. Chand and Co. Ltd., New Delhi, 74.

[13] United States of America Department of Transportation (1990) Specifications for Portland Cement Concrete Pavement Structures. Transport Research Board, 4, 205-230.

[14] Frias, M., Sánchez de Rojas, M.I., Garcia, N. and Luxon, M.P. (1994) Contribution of Toxic Elements: Hexavalent Chromium in Materials Used in the Manufacture of Cement. Cement and Concrete Research, 24, 533-541. https://doi.org/10.1016/0008-8846(94)90142-2

[15] Nigeria Industrial Standard (2003) NIS 445: Methods of Testing Cement: Chemical Analysis of Cement. 1534-1650.

[16] Nigeria Industrial Standard (1997) NIS 368: Methods of Testing Cement: Chemical Analysis of Cement. 2250-2757.

[17] Wheeler, B.D. (1998) Accuracy in X-Ray Spectrochemical Analysis as Related to Sample Preparation. Spectroscopy, 3, 24-33.

[18] British Standard Institution (BSI) (1995) BSEN 196-2: Methods of Testing Cement-Part 2: Chemical Analysis of Cement. British Standard Institution, London.

[19] Winter, N.B. (2015) Portland Cement and Its Major Constituent Phases. http://www.understsndingcement.com/parameters.html

[20] Hani, F.B. (2011) Chemical Analysis of Ordinary Portland Cement of Jordan. Chemical Analysis of Ordinary Portland Cement of Jordan, 14, 56-62.

[21] Rogers, A.R. (2005) Principles of Quality Control. A Laboratory Manual for West African Portland Cement Plc. Sagamu, Nigeria, 10-32.

[22] Neville, A.M. (1981) Properties of Concrete. 3rd Edition, Pitman Publishers Ltd., London, 1-61.

[23] Duda, W.H. (1988) Cement Data Book. Vol.1. Bauverlag GmbH, Berlin.

[24] Ali, K., Amin, N. and Shah, M. (2008) Chemical Study of Limestone and Clay for Cement Manufacturing in Darukhula Nizampur, District Nowshere (N.W.F.P.), Pakistan. Chinese Journal of Geochemistry, 27, 242-248. https://doi.org/10.1007/s11631-008-0242-8 
[25] Vidal, M.S. and Wing, O.U. (2001) Concrete Technology Theory and Practice. S. Chand \& Co. Ltd., New Delhi.

[26] Pandey, G.W. and Shukla, S.D. (1980) A Textbook of Chemical Technology. Vol. 1, Vikas Publishing House, New Delhi, 34-36.

[27] Faleye, F.J., Ogunnubi, S. and Olaofe, O. (2009) Chemical and Physical Analysis of Selected Cement Samples in Nigeria Market. Bangladesh Journal of Scientific and Industrial Research, 44, 41-50. https://doi.org/10.3329/bjsir.v44i1.2712

[28] Goktan, R.M. (2006) Discussion on ISRM Suggested Method for Determining the Shore Ha Value for Rocks'. International Journal of Rocks Mechanics and Mining Science, 436, 996-997. https://doi.org/10.1016/j.ijrmms.2005.12.011

[29] Paine, K.A. (2019) Physicochemical and Mechanical Properties of Portland Cements. In: Hewlett, P.C. and Liska, M., Eds., Lea's Chemistry of Cement and Concrete, 5th Edition, Butterworth-Heinemann, Oxford, 285-339. https://doi.org/10.1016/B978-0-08-100773-0.00007-1

[30] Taylor, H.W. (1990) Cement Chemistry. Academic Press Publishers, London.

[31] Lawrence, C.D. (1998) Effect of Proportion of Main Clinker Minerals. In: Lea's Chemistry of Cement and Concrete, 5th Edition, Butterworth-Heinemann, Oxford.

[32] Harrisson, A.M. (2019) Lime Saturation Factor. In: Hewlett, P.C. and Liska, M., Eds., Lea's Chemistry of Cement and Concrete, 5th Edition, Butterworth-Heinemann, Oxford, 268. 